\title{
A Sociological Study on Changing Family Structure in Karnataka
}

\author{
Dr.K.N.Doddamani, \\ Associate Professor of Sociology, College of Agriculture, Gulbarga, 585101 Karnataka, India
}

\begin{abstract}
The globalization in its literal sense is the process of transformation of local or regional things or phenomena into global ones .it can also be used to describe a process by which the people of the world are unified into a single society and function together. The process is a combination of economic, technical, sociocultural and political forces.

The traditional values were losing importance and new thinking new values were adding in society. Men and women will be treating equal in modern era. The new health treatment and facilities were opened to serve village people's health sector. All individuals were given equal opportunity in society. The village peoples way of life, structure of the family has been changed because of impact of liberlisation privatization and globalization in our country
\end{abstract}

Keywords: Impact of Globalization, Family-Structure, change

\section{Introduction}

Ever since the growth of human civilization, change has remained a consistent part of every society though there have been variations in its state and directions. At different phases of growth the processes of change have affected the various aspects of society. The processes of social change like: Modernization, Westernization, Urbanization and Sanskritization have contributed a lot in changing the Society. In the decade of 90's, the policy of Liberalization in the economic field, has resulted in frequent exchanges and a huge increase in the import-export between nations, and the development of various modes of communication has made the social exchanges between nations possible and easy. These social contacts have been defined in the form of globalization have also influenced the different aspects of Indian society. The primary unit of society and also primary source of socialization is family. The family has also been influenced by the effects of Globalization. Though it is the fact that processes like- Industrialization and Modernization have influences the traditional structure of family in the early years, but the changes have been rapid in the recent years on the Indian rural society, which has also passed through Globalization and Information. The revolution along with other social changes. Globalization is a concept of the emergence of a society that is based on the global outlook. Globalization is outcome of various social and cultural interactions between the masses

\section{Review of literature}

Though the precise definition of globalisation is still unavailable a few definitions worth viewing, Stephen Gill: defines globalisation as the reduction of transaction cost of transborder movements of capital and goods thus of factors of production and goods. Guy Brainbant: says that the process of globalisation not only includes opening up of world trade, development of advanced means of communication, internationalisation of financial markets, growing importance of MNC's, population migrations and more generally increased mobility of persons, goods, capital, data and ideas but also infections, diseases and pollution.

Tom G. Palmer of Cato Institute defines as the diminution or elimination of state enforced restrictions on exchanges across borders and the increasingly integrated and complex global system of production and exchange that has emerged as a result.

Thomas L.Friedman examines the impact of the flattening of the globe and argues that globalised trade, outsourcing, supply-changing, and political forces hve changed the world permanently, for both better and worse, he also argues that the pace of globalization in quickening and will continue to have a growing impact on business organization and practice.

Noam Chomsky argues that the word globalization is also used, in a doctrinal sense, to describe the neoliberal form of economic globalisation.

Globalisation advocates such as Jeffery sachs point to the above average drop in poverty rates in countries, such as china, where globalization has taken a strong foothold, compared to areas less affected by globalization, such as sub-saharan, Africa, where poverty rates have remained stagnant. 
India opened up the economy in the early nineties following a major crisis that led by a foreign exchange crunch that dragged the economy close to defaulting on loans. The response was a slew of Domestic and external sector policy measures partly prompted by the immediate needs and partly by the demand of the multilateral organisations. The new policy regime radically pushed forward in favour of amore open and market oriented economy. Major measures initiated as a part of the liberalisation and globalisation strategy in the early nineties included scrapping of the industrial licensing regime, reduction in the number of areas reserved for the public sector, amendment of the monopolies and the restrictive trade practices act, start of the privatisation programme, reduction in tariff rates and change over to market determined exchange rates.

Over the years there has been a steady liberalisation of the current account transactions, more and more sectors opened up for foreign direct investments and portfolio investments facilitating entry of foreign investors in telecom, roads, ports, airports, insurance and other major sectors.

The implications of globalisation for a national economy are many. Globalisation has intensified interdependence and competition between economies in the world market. This is reflected in Interdependence in regard to trading in goods and services and in movement of capital. As a result domestic economic developments are not determined entirely by domestic policies and market conditions. Rather, they are influenced by both domestic and international policies and economic conditions. It is thus clear that a globalising economy, while formulating and evaluating its domestic policy cannot afford to ignore the possible actions and reactions of policies and developments in the rest of the world. This constrained the policy option available to the government which implies loss of policy autonomy to some extent, in decision-making at the national level.

\section{Methodology}

The present paper is in reference to the Gulbarga districts under the Aland Taluka and within taluka the around 6 villages surrounding it, and the families undergoing change in their family structure. For the study around 6 villages in Aland taluka were selected around 6 villages were chosen of through purposive sample method. Thereafter for random sampling the Lottery method was applied out of which 300 respondents (50 persons per village) were taken into consideration for analyzing the role of globalization on their family structure. All the 300 respondents (male and female) were the head of their respective families. This study was based on the explorative and descriptive research design. The main basis of the research was the primary data, which was collected through the participant observation and through the interview schedule. In this research, for the collection of required facts the secondary data was also used on two major aspects of the changes in the family structure were being kept into mind while conducting the research (a) changes in family structure (b) An analysis has also been done on the change in the family functions in the present scenario. Change in the first aspect of family structure has been clarified by the following point: Change in the Structure of Family Due to the influence of Modernization and Globalization, there has been definite change in the family structure and the original structure of family has been undergoing changes. The nuclear Family has become the fashion and is taking the place of joint family system. In the past, the joint family system was much prevalent in this village community. But in the younger generation nuclear family system is practiced at larger scale. During research it also came in limelight that in the past majority of the families were large, but in the present time the family size has been changing rapidly. The table given below shows the family structure and size of the village community situating the Gulbarga district.

Table 1. Nature and size of family in the village community

\begin{tabular}{|l|l|l|l|}
\hline Sl.No & Nature of Family & Size of Family & Percentage \\
\hline 1 & Nuclear & Small (01-07 Members) & 73 \\
\hline 2 & Joint & Large (Above7Members) & 27 \\
\hline 3 & & Total & 100 \\
\hline
\end{tabular}

The above mentioned table deals with the about 73 percent families belong to small families below7 members i.e nuclear family and 27 percent families belongs to to large-size and come under the category of joint family systems.

The tendency of respondents in regard to family authority and decision-making in the changing scenario is demonstrates in the table given below: 
Table 2. The Tendency in regards to Family-Authority and Decision-Making in the Changing Scenario

\begin{tabular}{|l|l|l|l|l|l|}
\hline S1. No. & Nature of Decision & Only Husband & Only Wife & $\begin{array}{l}\text { Husband- } \\
\text { Wife both }\end{array}$ & Percentage \\
\hline $\mathbf{1}$ & Education related decision of children & $(27)$ & $(11)$ & $(62)$ & 100 \\
\hline $\mathbf{2}$ & Family expenditure related decisions & $(26)$ & $(17)$ & $(57)$ & 100 \\
\hline $\mathbf{3}$ & $\begin{array}{l}\text { Decision about Professional future of } \\
\text { young members of the family }\end{array}$ & $(33)$ & $(09)$ & $(58)$ & 100 \\
\hline $\mathbf{4}$ & Decision regarding agricultural -work & $(31)$ & $(14)$ & $(55)$ & 100 \\
\hline $\mathbf{5}$ & Decision regarding marriage & $(29)$ & $(21)$ & $(50)$ & 100 \\
\hline $\mathbf{6}$ & Decision regarding the arrival of Guests & $(34)$ & $(15)$ & $(51)$ & 100 \\
\hline $\mathbf{7}$ & $\begin{array}{l}\text { Decision regarding property - } \\
\text { buying/house building etc. }\end{array}$ & $(36)$ & $(14)$ & $(50)$ & 100 \\
\hline
\end{tabular}

The table No.2 reveals that the tendency of in regards to family decision making education related decision of children. The 27 percent only husbands will be taking decisions, 11 percent only wives will be taking decisions and 62 percent husband and wife both will be taking decisions. The family expenditure related decisions 26 percent only husbands, 17 percent only wives and 57 percent both husband and wife will be taking will be taking decisions. The decision about professional future of young members of the family respondents. The 33 percent only husbands, 09 percent only wife's and 58 percent both husband and wife's are taking the decisions. The Decision regarding agricultural -work 31 percent only husbands 14 percent only wives and 55 percent both husband and wife will be taking decisions. The Decision regarding marriage The 29 percent only husbands, 21 percent only wife's and 55 percent both husbands wife's will be taking decisions. The Decision regarding the arrival of Guests 34 percent husbands, 15 percent wives and 51 percent both husband and wives will be taking decisions. The Decision regarding property - buying/house building etc 36 percent only husbands, 14 percent only wives and 50 percent husband and wife both will be taking decisions.

Table 3. The Tendency in regard to Decrease in the Mutual Relations among Members of

\begin{tabular}{|l|l|l|l|}
\hline Sl. No & Nature of Relations & No. of Respondents & Percentage \\
\hline 1 & More Intimate & 21 & 07 \\
\hline 2 & Close & 132 & 44 \\
\hline 3 & Formal & 120 & 40 \\
\hline 4 & Sour Relations & 27 & 09 \\
\hline 5 & Total & 300 & 100 \\
\hline
\end{tabular}

Table No. 3 shows that about 07 percent respondents have more intimate relations, 44 percent respondents have close relationships,40 percent respondents have formal relations ,09 respondents have sour relations.

Table 4. The Tendency in Regards to Means of Treatment

\begin{tabular}{|l|l|l|l|}
\hline S.No & Various means and their use & No of Respondents & Percentage \\
\hline 1 & New means of treatment & 177 & 59 \\
\hline 2 & Traditional means of treatment & 123 & 41 \\
\hline & Total & 300 & 100 \\
\hline
\end{tabular}

The Tendency in Regards to Means of Treatment above table reveals that 59 percent respondents agree to the practice of modern means of treatment. They have viewed that because of the process of change and modernization, new means of treatment have come in use and they have replaced traditional means of treatments. Most of the respondents who approve of these modern means are educated and have modern ideas while the other 41 percent respondents accept that they prefer and approve of the traditional means of treatment these respondents feel that the traditional means do not give any adverse effect on health. The respondents who have expressed these views are traditional, illiterate and also have conventional attitude.

Table 5.The Change in the Economic and Financial Matters of the Family

\begin{tabular}{|l|l|l|l|}
\hline S.No & Change in economic financial matters & No of Respondents & Percentage \\
\hline 1 & yes change & 180 & 60 \\
\hline 2 & No change & 120 & 40 \\
\hline & Total & 300 & 100 \\
\hline
\end{tabular}

The Change in the Economic and Financial Matters of the Family,The above table reveals that the 60 percent respondents have agreed upon the fact that there has been change in the economic and financial matters 
of the family, while 40 percent respondents feel that there has been no change in the family functions in regard to economic and financial matters. The respondents who have accepted change agree to it that the economic and financial authority is not confined in the hands of the family head. It has got distributed among members of the households who are independent are self sufficient, and this change has also come due to the impact of information revolution, economic independence of men and women and the influence of modern education.

Table No.6 The Modern Education. In the present time,More Inclination of Parents and Guardians.

\begin{tabular}{|l|l|l|l|}
\hline S.No & Inclination towards education & No of Respondents & Percentage \\
\hline 1 & Private \& convent schools & 186 & 62 \\
\hline 2 & Necessity of education as normal & 114 & 38 \\
\hline & Total & 300 & 100 \\
\hline
\end{tabular}

The above table deals with62 percent respondents more inclination towards Private schools, Convent schools compared to the Government schools. The respondents have accepted that education has become essential in the present scenario; while 38 percent respondents consider the necessity of education as normal.

\section{Findings}

The 73 percent families belong to small families below7 members i.e nuclear family and 27 percent families belongs to to large-size and come under the category of joint family systems.

The tendency of in regards to family decision making education related decision of children. The 27 percent only husbands will be taking decisions, 11 percent only wives will be taking decisions and 62 percent husband and wife both will be taking decisions. The family expenditure related decisions 26 percent only husbands, 17 percent only wives and 57 percent both husband and wife will be taking will be taking decisions. The decision about professional future of young members of the family respondents. The 33 percent only husbands, 09 percent only wife's and 58 percent both husband and wife's are taking the decisions. The Decision regarding agricultural -work 31 percent only husbands 14 percent only wives and 55 percent both husband and wife will be taking decisions. The Decision regarding marriage The 29 percent only husbands, 21 percent only wife's and 55 percent both husbands wife's will be taking decisions. The Decision regarding the arrival of Guests 34 percent husbands, 15 percent wives and 51 percent both husband and wives will be taking decisions. The Decision regarding property - buying/house building etc 36 percent only husbands, 14 percent only wives and 50 percent husband and wife both will be taking decisions.

About 07 percent respondents have more intimate relations, 44 percent respondents have close relationships, 40 percent respondents have formal relations ,09 respondents have sour relations.

The Tendency in Regards to Means of Treatment above table reveals that 59 percent respondents agree to the practice of modern means of treatment. They have viewed that because of the process of change and modernization, new means of treatment have come in use and they have replaced traditional means of treatments. Most of the respondents who approve of these modern means are educated and have modern ideas while the other 41 percent respondents accept that they prefer and approve of the traditional means of treatment these respondents feel that the traditional means do not give any adverse effect on health. The respondents who have expressed these views are traditional, illiterate and also have conventional attitude.

The Change in the Economic and Financial Matters of the Family, The above table reveals that the 60 percent respondents have agreed upon the fact that there has been change in the economic and financial matters of the family, while 40 percent respondents feel that there has been no change in the family functions in regard to economic and financial matters. The respondents who have accepted change agree to it that the economic and financial authority is not confined in the hands of the family head. It has got distributed among members of the households who are independent are self sufficient, and this change has also come due to the impact of information revolution, economic independence of men and women and the influence of modern education.

The 62 percent respondents more inclination towards Private schools, Convent schools compared to the Government schools. The respondents have accepted that education has become essential in the present scenario; while 38 percent respondents consider the necessity of education as normal.

\section{Conclusion}

The present research paper concludes that there have been many changes found in the village community and this has been because of the impact of globalization. But this change mainly happens in the form of limited changes that have been occurred in their family structure. This change is related mainly to the both aspects of family structure but the functional aspect of change has been demonstrated in a limited way. This community has it neither altogether given up its traditional practices nor has it totally accepted modernization in regard to family structure. The social functioning is operational in between the background of globalization and family values. It also reflects that the family structure has been incapable in following its traditional collectivity 
in the modern scenario, but even then the basic characteristics of traditionality is existent and it has kept the family together and one. In brief, we can say that the traditional values are gradually losing their importance and the place is taken by the modern values. As a result, the community is prone to change in its family structure due to the impact of globalization which can also be referred to as transitional phase of society.

\section{References}

[1]. Doshi, S.L. 2002. Modernity, Post-Modernity and Neo-Sociological Theories. Jaipur and New Delhi: Rawat Publications.

[2]. Giddens, Anthony. 1990.The Consequences of Modernity. Cambridge: Polity Press.

[3]. Goode,W.J. \& Hatt. P.K. 1983. -Methods in Social Research. Auckland: McGraw Hill International.

[4]. Gore, M.S. 1968. Urbanization and Family Change in India. Bombay: Popular Prakashan.

[5]. Jain, Shobhita. 2002. Bharat men Parivar, Vivah aur Natedari. Jaipur: Rawat Publications.

[6]. Pathak, Avijit. 2003. - Post war thinking: Need for egalitarian Globalization, Mainstream, 41 (22). 2003 (17 May): 11-12.

[7]. Ross, A.D. 1961. Hindu Family in its Urban Setting. Toronto: Oxford University Press. Robertson. 1997. - Social Theory and

[8]. Global Culture. New Delhi: Sage Publications. [8] Singh, Yogendra. 2000. Culture Change in India. Jaipur: Rawat Publications.

[9]. Waters, Malcolm. 1998. Globalization. London: Routledge.

[10]. Weber, Max. 1947.Theory of Social and Economic Organization. New York: Oxford University Press.

[11]. Globalisation and Poverty: Centre for International Economics, Australia.

[12]. wider annual lecture 6: Winners and Losers over two centuries of Globalisation: Jeffery G. Williamson.

[13]. Globalisation Trend and Issues - T.K.Velayudham, Page 3, 66.

[14]. "Globalisation and Liberalisation" Prospects of New World Order - Dr.A.K.Ojha, Third Concept - An International Journal of Ideas, Aug 2002.

[15]. The Indian and Global Business - Jan 2004, Page 30.

[16]. Globalisation: Imperatives, Challenges and the Strategies, Page 39 